\title{
Assessment of Gross Chemical Composition, Mineral Composition, Vitamin Composition and Amino Acids Composition of Wheat Biscuits and Wheat Germ Fortified Biscuits
}

\author{
Hanan M. K. E. Youssef \\ Home Economic Department, Faculty of Specific Education, Ain Shams University, Cairo, Egypt \\ Email: hanankamaly@yahoo.com
}

Received 30 March 2015; accepted 12 July 2015; published 15 July 2015

Copyright @ 2015 by author and Scientific Research Publishing Inc. This work is licensed under the Creative Commons Attribution International License (CC BY). http://creativecommons.org/licenses/by/4.0/ (c) (i) Open Access

\begin{abstract}
Wheat germ is reckoned valuable healthful functional food. The present investigation was performed to assess nutritional status of wheat biscuits and wheat germ fortified biscuits. Study included determination of gross chemical composition, caloric value, minerals $\mathrm{CMn}, \mathrm{Ca}, \mathrm{Fe}, \mathrm{Cu}, \mathrm{P}, \mathrm{Na}$ and $\mathrm{K}$ ), vitamins (C, Folic acid, $\mathrm{A}$, and $\mathrm{E}$ ), and amino acid composition of wheat biscuits and 15\%, $\mathbf{2 0 \%}$ wheat germ fortified biscuits. Likewise physical and sensory characteristics of studied biscuits were assessed. The data revealed that $20 \%$ wheat germ fortified biscuits proved to be nutritious functional healthful food. It improved both physical, sensory characteristics and recorded the highest crude protein $(12.20 \%)$, crude fiber $(2 \%)$, and the least fat $(9.63 \%)$, moisture $(3.01 \%)$, and caloric value ( $436.31 \mathrm{Kcal} / \mathbf{1 0 0 g}$ ). While it recorded the highest $\mathrm{Mn}$ and Cu contents as well as increased vitamins C, Folic acid, A, and E. Besides, $20 \%$ wheat germ fortified biscuits increased all the eight essential amino acids contents resulting in an improvement of the nutritive value of wheat biscuits. Therefore it could be recommended for caloric reduced diets for obese and overweight persons. Likewise, it should be increasing interest as an ingredient in the industry as functional and healthy foods formulations as biscuits, bread and cakes.
\end{abstract}

\section{Keywords}

Wheat Biscuits, 15\%, 20\% Fortified Wheat Biscuits, Gross Chemical Composition, Minerals, Vitamins, Amino Acids Caloric Value, Physical, Sensory Characteristics 


\section{Introduction}

Wheat germ constitutes about $2.5 \%$ - 3\% of the wheat seed and is reckoned valuable healthful functional food [1]-[5]. The mean proximate chemical composition of wheat germ was: $10.80 \%, 26.50 \%, 8.56 \%$ and $4.18 \%$ for moisture, crude protein, crude fat and ash content; respectively, on dry basis [6] [7]. While [8] reported that wheat germ contained approximately $10 \%$ - 15\% lipids, $26 \%$ - 35\% proteins, $17 \%$ sugars, $1.5 \%-4.5 \%$ fibre and $4 \%$ minerals, as well as significant quantities of bioactive compounds, such as tocopherols (300 - $740 \mathrm{mg} / \mathrm{kg} \mathrm{DM}$ ), phytosterols (24 - $50 \mathrm{mg} / \mathrm{kg}$ ), policosanols (10 mg/kg), carotenoids (4 - $18 \mathrm{mg} / \mathrm{kg})$, thiamin (15 - $23 \mathrm{mg} / \mathrm{kg}$ ) and riboflavin (6 - $10 \mathrm{mg} / \mathrm{kg})$. [9] stated that the raw wheat germ contained $11 \%$ moisture, $31.4 \%$ crude protein, $18.5 \%$ dietary fibre and $7 \%$ fat.

On the other hand, [6] found that the mean mineral composition of wheat germ was: $365.1+7.21,0.6+0.03$, $9.45+0.35,1365.1+21.35,310.3+7.49,13.0+1.41,775.2+7.35$ and $9.05+0.07(\mathrm{mg} / 100 \mathrm{~g})$ for $\mathrm{Ca}, \mathrm{Cu}, \mathrm{Fe}$, $\mathrm{K}, \mathrm{Mg}, \mathrm{Mn}, \mathrm{P}$ and Zn contents, respectively (on dry basis). While, [5] reported that the mean mineral composition of raw wheat germ was: 9.07, 11.24, 1.59, 17.38, 312, 100, 70, 440, 705, 344, 300 (mg/100g) for Fe, Mn, $\mathrm{Cu}, \mathrm{Zn}, \mathrm{Mg}, \mathrm{Ca}, \mathrm{Na}, \mathrm{K}, \mathrm{P}, \mathrm{S}$ and Se contents, respectively.

On the other hand, wheat germ contained high vitamin, dietary fibre contents and a low fat content [10]. While, [11] found that the mean vitamins of wheat germ were (2.00 \pm 0.042$) ;(0.22 \pm 0.036)$ and $(7.40 \pm 0.35)$ $\mathrm{mg} / 100 \mathrm{~g}$ for thiamine, riboflavin and niacin contents, respectively. [12] [13] outlined that the wheat germ is the nutritionally richest part of the wheat seed. It is one of the few plant parts in nature in which the entire vitamin B-complex is found. [5] reported that the raw wheat germ contained 10343.23 IU/100g (vitamin A); 1312 IU/100g (vitamin E); and $98.45 \mathrm{mg} / 100 \mathrm{~g}$ (vitamin C).

Furthermore, [14] [15] identified that the mean essential amino acid profile of defatted wheat germ was: (2.92, 1.73), (6.64, 1.11), (6.69, 2.32), (1.64, 0.25), (4.06, 1.04), (4.50, 0.93), (1.15, 0.20), and $(4.53,1.40)$ (g/100g) for isoleucine, leucine, lysine, methionine, phenylalanine, threonine, tryptophan, and valine. While, [5] found that the raw wheat germ contained the essential amino acids: 4.06, 10.47, 10.26, 2.08, 5.03, 2.54, 1.80; and $6.21(\mathrm{~g} / 100 \mathrm{~g})$ for isoleucine, leucine, lysine, Methionine, phenylalanine, threonine, tryptophan and valine.

The fortification of bakery products and bakers confectionery with wheat germ, i.e. bread, toast bread, biscuits, and cakes were reported by several authors, i.e. [2] [16]-[27].

This investigation was designed to produce fortified wheat biscuits with wheat germ, which has better nutritional value, available and relatively cheap and does not require any preparation efforts before using. The objectives of this investigation were to study the gross chemical composition, caloric value, the mineral composition, the vitamin composition, the amino acid composition as well as physical and sensory quality attributes of wheat biscuits and wheat germ fortified biscuits.

\section{Materials and Methods}

\subsection{Materials}

$5 \mathrm{~kg}$ wheat flour $72 \%$ extraction hard red winter and $3 \mathrm{~kg}$ wheat germ were obtained from El-Haram Milling Company, Faesal, Giza in December 2014. Sugar powder, powdered milk, butter, sodium chloride, ammonium bicarbonate, sodium bicarbonate and baking powder were purchased from Cairo local market in December 2014.

Both wheat flour and wheat germ were kept in glass containers at $4^{\circ} \mathrm{C}$ in the refrigerator till the analysis.

\subsection{Technological Process}

\subsubsection{Biscuit Formula and Ingredients}

Control biscuit dough was prepared according to the formula presented in Table 1, [28]. The supplemented biscuits with wheat germ were prepared using the same formula except for replacing the wheat flour with $15 \%$ and $20 \%$ of wheat germ.

\subsubsection{Dough Preparation}

Powdered sugar and butter were creamed in Braun Mixer with a flat beater for 2 minutes at 5 rpm. Water containing sodium chloride, ammonium bicarbonate, powdered milk, sodium bicarbonate and baking powder were added to the cream and mixed for 5 minutes at $125 \mathrm{rpm}$ to obtain a homogenous cream. Thereafter the flour was 
Table 1. Wheat flour biscuits formula*.

\begin{tabular}{cc}
\hline Ingredients & Gram \\
\hline Wheat flour (72\% extraction rate) & 100 \\
Powdered sugar & 20.00 \\
Sodium chloride & 0.50 \\
Powdered milk & 10.00 \\
Butter & 40.00 \\
Ammonium bicarbonate & 1.00 \\
Sodium bicarbonate & 0.50 \\
Baking powder & 0.50 \\
Water & 25.00 \\
\hline
\end{tabular}

${ }^{*}[28]$.

added slowly to the above cream and was mixed for 2 minutes at $60 \mathrm{rpm}$ to obtain biscuit dough [29].

\subsubsection{Preparation of Biscuits}

The dough was sheeted to thickness of about $3 \mathrm{~mm}$ using Atlas Brand Rolling Machine. The sheeted dough was cut into round shape using a $45 \mathrm{~mm}$ diameter cutter and baked on an alluminium tray in an electric oven at $180^{\circ} \mathrm{C}$ for 6 minutes. The biscuit was cooled for 30 minutes, packed in polyethylene bags stored under desiccation [30] [31].

\subsubsection{Preparation of Different Blends of Biscuits}

\section{Blends of biscuits:}

Blends of biscuits were prepared using wheat flour 72\% extraction rate as control or those which were substituted with $15 \%$ and $20 \%$ wheat germ.

\section{Methods}

\subsection{Physical Valuation of Biscuits}

Biscuit were evaluated for height $(\mathrm{cm})$, width $(\mathrm{cm})$, spread ratio and spread factor. Five biscuits were used for the evaluations from the three studied biscuits and averages were recorded. The spread ratio and spread factor were calculated according to [31] using the following equations:

$$
\begin{gathered}
\text { Spread ratio }=\frac{\text { Width }}{\text { Height }} \\
\text { Spread factor }=\frac{\text { Spread ratio of sample }}{\text { Spread ratio of control }} \times 100
\end{gathered}
$$

\subsection{Sensory Evaluation of Biscuits}

Sensory evaluation for the color, texture, taste, odor, and overall acceptability were done in order to determine consumer acceptability. A numerical hedonic scale ranging from 1 to 10 (1 is very bad and 10 for excellent) was used for sensory evaluation [32]. Ten experienced judges participated in the test.

\subsection{Gross Chemical Composition}

Moisture, protein, fat, crude fiber and ash were determined according to the methods described in [33].

Total carbohydrates content was calculated by difference (100-total gross chemical composition) on dry weight basis according to [33]. 
The caloric value was calculated according to the method of [34].

\subsection{Mineral Composition}

Total content of elements was carried out using a mixture of $\left(\mathrm{HClO}_{4} / \mathrm{HNO}_{3}\right)$ according to (Inductive Coupled Plasma Emission Spectrometry). The elements Ca, Mn, Cu and Fe) were determined using ICP (ICAP6200) according to [35]. Sodium and potassium contents were estimated using Flame Photometry (Jenway PFP7) according to the procedure reported by [36]. Phosphorus was estimated using GBC Atomic Absorption 906A according to the procedure described in [37].

\subsection{Vitamins Assay}

Vitamin C was determined using Aglient HPLC (uv-vis) as described by [38]. Folic acid was determined using Surveyour HPLC ((PDA) as described by [39]. Vitamins A and E were determined using Schmidzua HPLC (PDA) as described by [40].

\subsection{Amino Acids Composition}

Acid hydrolysis was carried out according to the method of [41]. The dried and defatted grinding sample (Ca. $0.2 \mathrm{~g}$ ) was hydrolyzed with $6 \mathrm{~N} \mathrm{HCl}(10 \mathrm{ml})$ in sealed tube, heated in an oven at $110^{\circ} \mathrm{C}$ for 24 hours. The resulting solution was completed to $25 \mathrm{ml}$ with de-ionized water. After filtration, $5 \mathrm{ml}$ of hydrolyzate was evaporated until to be free from $\mathrm{HCl}$ vapor.

Then the residue was dissolved in diluting citrate buffer ( $\mathrm{pH}$ 2.2). The system used for the analysis was High Performance Amino Acid Analyzer, Model: Ingos AAA400.

\subsection{Tryptophan Determination}

Tryptophan was determined by the colormetric method using UV-1601PC, Shimadzu. UV-Visible spectrophotometer $(550 \mu \mathrm{m})$ according to the method described by [42].

\section{Results and Discussion}

\subsection{Physical Characteristic of Biscuits}

Wheat germ had been considered as a functional food supplement in several bakery products. The mean values of physical characteristics of wheat biscuits and fortified wheat biscuits are presented in Table 2 and Figures 1-3.

The data recorded a gradual increment of spread ratio of both $15 \%$ and $20 \%$ wheat germ fortified biscuits ranging from 7.50 to 7.87 ; respectively. Considering the spread factor of control biscuits $(100 \%$ wheat flour $72 \%$ extraction ratio biscuits) as 100, results given in Table 2 indicated that it increased to 109 and 114 for 15\% and $20 \%$ wheat germ fortified biscuits; respectively.

\subsection{Sensory Characteristics of Biscuits}

The sensory characteristics of the studied wheat biscuits as influenced by incorporation of $15 \%$ and $20 \%$ wheat germ are outlined in Table 3. The data revealed that both fortified wheat biscuits with $15 \%$ and $20 \%$ wheat

Table 2. Physical characteristics of $100 \%$ wheat flour $72 \%$ extraction biscuits (control) and wheat flour biscuits supplemented with $15 \%$ and $20 \%$ wheat germ.

\begin{tabular}{|c|c|c|c|c|}
\hline Biscuit samples & Width $^{\mathrm{a}}(\mathrm{cm})$ & Thickness $^{\mathrm{b}}$ (cm) & Spread ratio $^{c}$ & Spread factor \\
\hline $100 \%$ wheat flour- $72 \%$ extraction biscuits (control) & 5.5 & 0.8 & 6.87 & 100.00 \\
\hline $15 \%$ fortified wheat biscuits with wheat germ & 6.0 & 0.8 & 7.50 & 109.00 \\
\hline $20 \%$ fortified wheat biscuits with wheat germ & 6.3 & 0.8 & 7.87 & 11400 \\
\hline
\end{tabular}

${ }^{\mathrm{a}}$ Width of 5 biscuits in series; ${ }^{\mathrm{b}}$ Thickness of 5 biscuits in series; ${ }^{\mathrm{c}}$ Width/thickness; ${ }^{\mathrm{d}} \frac{\text { Spread ratio of sample }}{\text { Spread ratio of control }} \times 100$. 


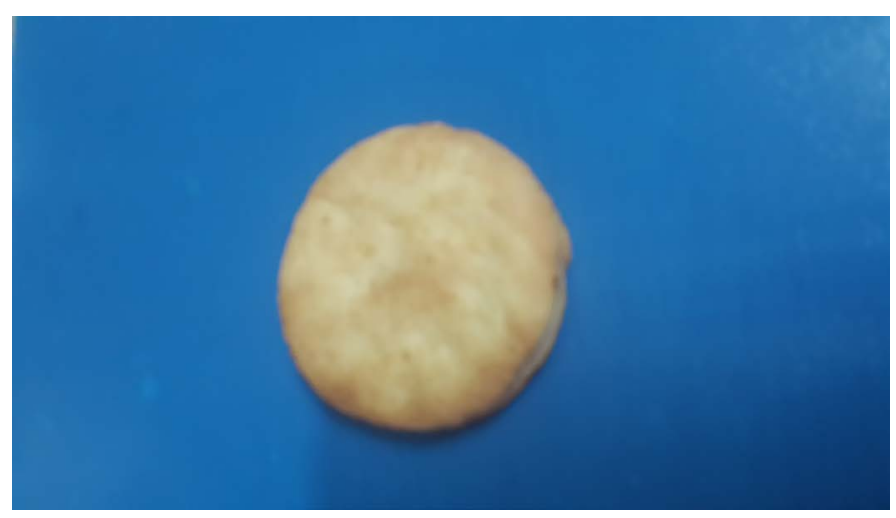

Figure 1. 100\% wheat flour-72\% extraction biscuits.

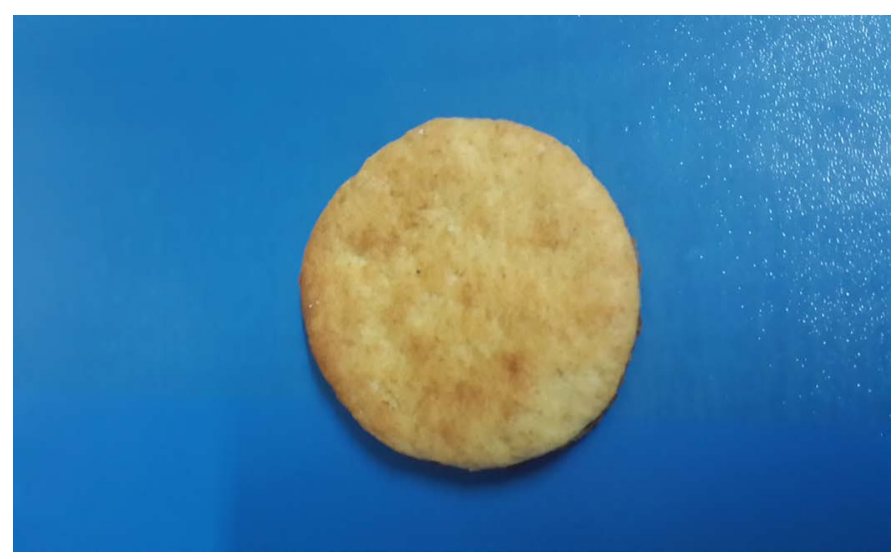

Figure 2. 15\% wheat germ fortified wheat biscuits.

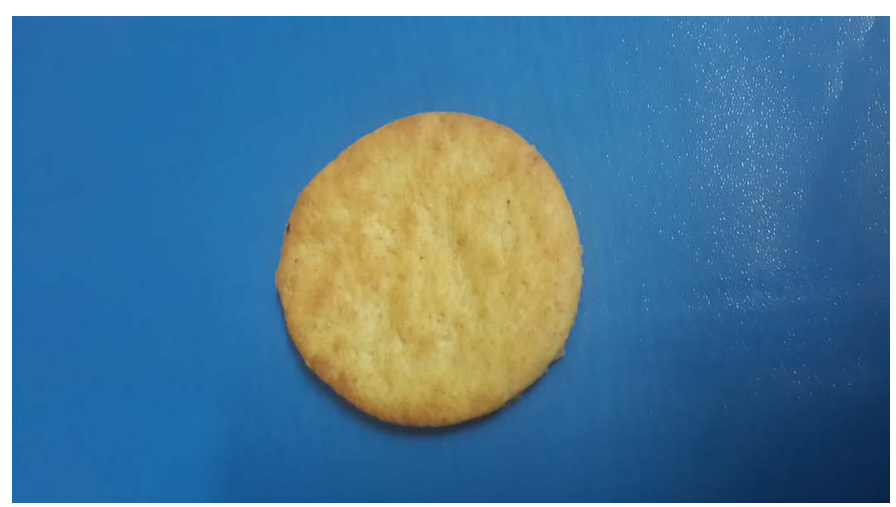

Figure 3. 20\% wheat germ fortified wheat biscuits.

Table 3. Sensory characteristics of $100 \%$ wheat flour $72 \%$ extraction biscuits (control) and wheat flour biscuits supplemented with $15 \%$ and $20 \%$ wheat germ*.

\begin{tabular}{|cccccc|}
\hline Biscuits samples & Color & Texture & Taste & Odor & $\begin{array}{c}\text { Overall } \\
\text { acceptability }\end{array}$ \\
\hline 100\% wheat flour-72\% extraction biscuits (control) & 7.00 & 7.50 & 7.50 & 8.00 & 7.50 \\
15\% fortified wheat biscuits with wheat germ & 8.00 & 8.20 & 7.80 & 8.20 & 7.90 \\
20\% fortified wheat biscuits with wheat germ & 8.00 & 8.30 & 800 & 7.20 & 8.20 \\
\hline
\end{tabular}

${ }^{*}$ Mean of ten replicates. 
germ improved all studied sensory characteristics. However, the best scores were recorded for $20 \%$ wheat germ fortified biscuits. Such data are in good agreement with [19] [23]-[25] findings.

\subsection{Gross Chemical Composition of Biscuits}

The mean value of gross chemical composition and caloric value of wheat biscuits and fortified wheat biscuits with $15 \%$ and $20 \%$ are given in Table 4 . The data revealed that incorporation of $15 \%$ wheat germ in wheat flour biscuits increased crude protein, fat and crude fiber as well as moisture contents and caloric value. However, such supplementation decreased carbohydrates content. While, $20 \%$ wheat germ supplemented wheat biscuits recorded the highest crude protein (12.20\%), crude fiber (2\%) and the least fat (9.63\%), moisture contents (3.01\%) and caloric value (436.31 K Cal/100g) as well. Such data are in good accordance with [22]-[43] findings.

\subsection{Minerals Composition of Biscuits}

The mean values of minerals composition of wheat biscuits and 15\%, 20\% wheat germ fortified biscuits are outlined in Table 5 . The data revealed that $15 \%$ wheat germ supplemented wheat biscuits had the highest $\mathrm{Ca}, \mathrm{Fe}, \mathrm{P}$, Na and K contents; respectively. Meanwhile, 20\% wheat germ supplemented wheat biscuits had the highest Mn and $\mathrm{Cu}$ contents, respectively. Such data coincide with [24] [25] [44]-[48] findings.

\subsection{Vitamins Content of Biscuits}

The data outlined in Table 6 represented the mean values of vitamins content in wheat biscuits and 15\%, 20\% wheat germ fortified biscuits. The data revealed that $15 \%$ wheat germ fortified biscuits increased vitamin $\mathrm{C}$ and vitamin E contents. While, 20\% wheat germ increased all studied vitamins, i.e., C, Folic acid, A and E contents than that of wheat biscuits. Such data are in agreement with [43] [49]-[51] findings.

\subsection{Amino Acids Content of Biscuits}

The amino acid composition data of wheat biscuits and 15\%, 20\% wheat germ fortified biscuits are presented in Table 7. The outlined data revealed that $15 \%$ wheat germ fortified biscuits increased isoleucine, lysine, and phenylalanine contents. While, 20\% wheat germ fortified biscuits increased all the eight essential amino acids contents, resulting in an improvement of the nutritive value of wheat biscuits. The data are in good agreement

Table 4. Gross chemical composition and caloric value of wheat flour biscuits and 15\%, $20 \%$ wheat germ flour fortified wheat biscuits (on dry weight basis)* .

\begin{tabular}{lcccccc}
\hline Biscuit's samples & Moisture & Ash & Protein & Fat & $\begin{array}{c}\text { Crude fiber } \begin{array}{c}\text { Total } \\
\text { carbohydrates }\end{array} \\
\text { Kc/100g }\end{array}$ \\
\hline $\begin{array}{l}\text { Wheat flour biscuits (72\% extraction rate) } \\
\begin{array}{l}\text { 15\% wheat germ flour fortified wheat } \\
\text { flour biscuits }\end{array}\end{array}$ & 3.75 & 0.95 & 9.11 & 11.75 & 1.00 & 77.19 \\
$\begin{array}{l}\text { 20\% wheat germ flour fortified wheat } \\
\text { flour biscuits }\end{array}$ & 3.01 & 0.96 & 0.96 & 10.25 & 13.12 & 2.00 \\
\hline
\end{tabular}

*Mean of three replicates.

Table 5. Mineral content of wheat flour biscuits and 15\%, 20\% wheat germ flour fortified wheat flour biscuits on dry basis*.

\begin{tabular}{lcccccc}
\hline Biscuit's samples & $\begin{array}{c}\mathbf{M n} \\
\mathbf{m g} / \mathbf{k g}\end{array}$ & $\begin{array}{c}\mathbf{C a} \\
\mathbf{m g} / \mathbf{k g}\end{array}$ & $\begin{array}{c}\mathbf{F e} \\
\mathbf{m g} / \mathbf{k g}\end{array}$ & $\begin{array}{c}\mathbf{C u} \\
\mathbf{m g} / \mathbf{k g}\end{array}$ & $\begin{array}{c}\mathbf{P} \\
\mathbf{m g} / \mathbf{k g}\end{array}$ & $\begin{array}{c}\mathbf{N a} \\
\mathbf{m g} / \mathbf{k g}\end{array}$ \\
$\begin{array}{l}\text { Wheat flour biscuits (72\% extraction rate) } \\
\begin{array}{l}\text { 15\% wheat germ flour fortified wheat } \\
\text { flour biscuits }\end{array}\end{array}$ & 5.79 & 1635 & 173.05 & 0.00 & 1299.78 & 6073 \\
$\begin{array}{l}\text { 20\% wheat germ flour fortified wheat } \\
\text { flour biscuits }\end{array}$ & 40.18 & 1773 & 226.65 & 0.27 & 2923.24 & 6563 \\
\hline
\end{tabular}

${ }^{*}$ Mean of three replicates. 
Table 6. Vitamin content of wheat flour biscuits and 15\%, 20\% wheat germ flour fortified wheat flour biscuits on dry weight basis ${ }^{*}$.

\begin{tabular}{|c|c|c|c|c|}
\hline Biscuit's samples & $\begin{array}{c}\text { Vitamin C } \\
\text { mg/100g }\end{array}$ & $\begin{array}{l}\text { Folic acid } \\
\text { mg/100g }\end{array}$ & $\begin{array}{c}\text { Vitamin A } \\
\mathrm{mg} / \mathbf{1 0 0 g}\end{array}$ & $\begin{array}{c}\text { Vitamin E } \\
\mathrm{mg} / \mathbf{1 0 0 g}\end{array}$ \\
\hline Wheat flour biscuits (72\% extraction rate) & 0.00 & 0.071 & 1354 & 4.00 \\
\hline $15 \%$ wheat germ flour fortified wheat flour biscuits & 2.3 & 0.067 & 1155.30 & 4.60 \\
\hline $20 \%$ wheat germ flour fortified wheat flour biscuits & 1.9 & 0.080 & 1454 & 5.70 \\
\hline
\end{tabular}

*Mean of three replicates.

Table 7. Amino acid composition of wheat flour biscuits and 15\%, $20 \%$ wheat germ flour fortified wheat flour biscuits g/100g protein of dry weight basis.

\begin{tabular}{|c|c|c|c|c|c|c|c|c|}
\hline Biscuit's samples & Isoleucine & Leucine & Lysine & Methionine & Phenylalanine & Threonine & Tryptophan & Valine \\
\hline $\begin{array}{l}\text { Wheat flour biscuits ( } 72 \% \\
\text { extraction) }\end{array}$ & 0.67 & 5.24 & 1.17 & 0.96 & 1.02 & 0.67 & 0.48 & 3.58 \\
\hline $\begin{array}{l}15 \% \text { wheat germ flour fortified } \\
\text { wheat flour biscuits }\end{array}$ & 0.76 & 5.22 & 2.01 & 0.92 & 1.20 & 1.12 & 0.50 & 3.36 \\
\hline $\begin{array}{l}20 \% \text { wheat germ flour fortified } \\
\text { wheat flour biscuits }\end{array}$ & 0.80 & 6.04 & 2.76 & 0.99 & 1.28 & 1.21 & 0.56 & 3.80 \\
\hline
\end{tabular}

with [22] [46] [47] [52]-[54] findings.

\section{Conclusion}

In conclusion, 20\% wheat germ fortified biscuits proved to be nutritious functional and healthful food. Moreover, it could be recommended for caloric reduced diets for obese and over-weight persons. Likewise, it should be increasing interest as an ingredient in the food industry such as functional and healthy foods formulations as biscuits, bread, and cakes.

\section{References}

[1] Sjovall, O., Virtalaine, T., Lapvetelainen, A.M. and Kallio, H. (2000) Development of Rancidity in Wheat Germ Analyzed by Headspace Gas Chromatography and Sensory Analysis. Journal of Agricultural and Food Chemistry, 48, 3522-3527. http://dx.doi.org/10.1021/jf981309t

[2] Sidhu, J.S., Al-Hooti, S.N., Al-Sager, J.M. and Al-Othman, A. (2001) Studies on the Development of Pan Bread Using Raw Wheat Germ. Journal of Food Quality, 24, 235-247. http://dx.doi.org/10.1111/j.1745-4557.2001.tb00605.x

[3] Arrigoni, E., Jorger, F., Kolloffelm, B., Roulet, I., Herensperger, M., Meile, L. and Amado, R. (2002) In Vitro Fermentability of a Commercial Wheat Germ Preparation and Its Impact on the Growth of Bifidobacteria. Food Research International, 35, 475-481. http://dx.doi.org/10.1016/S0963-9969(01)00146-6

[4] Hessen, K.R.F. (2003) Chemistry of Cereals and Cereals Products. Dar El-Kotob for Publication and Distribution. Cairo (In Arabic).

[5] El-Manfaloty, M.M.H.M.L. (2010) Nutritional and Biological Assessment of Wheat Germ and Its Effect on Immune System in the Experimental Rats. Ph.D. Thesis, Faculty of Specific Education, Ain Shams University, Cairo.

[6] Bilgicli, N., Elgun, A., Herken, E.N., Turker, S., Ertas, N. and Ibanoglu, S. (2006) Effect of Wheat Germ and Wheat Bran on the Chemical, Nutritional and Sensory Quality of Tarhana, a Fermented Wheat Flour-Yoghurt Product. Journal of Food Engineering, 77, 680-686. http://dx.doi.org/10.1016/j.jfoodeng.2005.07.030

[7] Bilgicli, N. and Ibanoglu, S. (2007) Effect of Wheat Germ and Wheat Bran on the Fermentation Activity, Phytic Acid Content and Color of Terhana, a Wheat Flour-Yoghurt Mixture. Journal of Food Engineering, 78, 681-686. http://dx.doi.org/10.1016/j.jfoodeng.2005.11.012

[8] Brandolini, A. and Hidalgo, A. (2012) Wheat Germ: Not Only a By-Product. International Journal of Food Sciences and Nutrition, 63, 71-74. http://dx.doi.org/10.3109/09637486.2011.633898

[9] Sudha, M.L., Srivastava, A.K. and Leelavathi, K. (2007) Studies on Pasting and Structural Characteristics of Thermally Treated Wheat Germ. European Food Research and Technology, 225, 351-357.

http://dx.doi.org/10.1007/s00217-006-0422-x 
[10] Muehlthaeuser, H. (2003) Grain Germs for Bread and Other Baked Goods. Getreidekeimlinge für Brot und Backwaren. In: Getreide, Mehl und Brot, 57, 28-30, 35-39.

[11] Marshall, P.A., Vandepeer, J.M., Pant, I., Trenerry, V.C., Scheelings, P. and Buick, D.R. (1997) The Development and Evaluation of Secondary Food Reference Materials for the Determination of Cholesterol, Fatty Acids and Selected Water-Soluble Vitamins in Foods. Food Chemistry, 58, 269-276. http://dx.doi.org/10.1016/S0308-8146(96)00244-0

[12] Onstand, D. (1996) Whole Foods Companion: A Guide for Adventurous Cooks, Curious Stoppers and Lovers of Natural Foods. Chelsea Green Publishing Company, White River Junction.

[13] Wood, J. (1999) The New Whole Food Encyclopedia. Penguin Books, New York.

[14] Zhu, K., Zhou, K.H., and Qian, H.F. (2006) Protein Extracted from Defatted Wheat Germ: Nutritional and Structural Properties. Cereal Chemistry, 83, 69-75. http://dx.doi.org/10.1094/CC-83-0069

[15] Arshad, M.U., Anjum, F.M. and Zahoor, T. (2007) Nutritional Assessment of Cookies Supplemented with Defatted Wheat Germ. Food Chemistry, 102, 123-128. http://dx.doi.org/10.1016/j.foodchem.2006.04.040

[16] Semenyuk, V.F. and Dyakonova, A.K. (1986) Chemical Composition of Wheat Germ. Pishchevaya i Pereabatyvayushchaya Promyshlennost, No. 5, 37.

[17] Wennermark, B. and Jaegerstand, M. (1992) Breadmaking and Storage of Various Wheat Fractions Affect Vitamin E. Journal of Food Science, 57, 1205-1209. http://dx.doi.org/10.1111/j.1365-2621.1992.tb11300.x

[18] Sidhu, J.S., Al-Hooti, S.N. and Al-Sager, J.M. (1998) Effect of Adding Wheat Bran and Germ Fractions on the Chemical Composition of High Fiber Toast Bread. Food Chemistry, 67, 365-371. http://dx.doi.org/10.1016/S0308-8146(99)00123-5

[19] Abu-Elmatti, S., Abd-El-Hady, M.M., El-Sahi, K.M. and El-Badawi, A.A. (2000) Enrichment of Two Types of Biscuits by Wheat Germ. Egyptian Journal of Food Science, 24, 331-344.

[20] Bouchard, C., Gausseres, N., Jimenez, L., Attal, F., Bonnot, I., Notardonato, L. and Rocher, P. (2003) Biscuit Product Permitting Nutritional Prevention of Oxidative Stress. French Patent Application.

[21] Constandache, M. (2007) The Influence of Fortification of Bread with Exogenous Proteins on the Protein Digest Ability. Journal of Agroalminentary Processes and Technologies, 13, 461-466.

[22] Constandache, M., Radu, S. and Condrea, E. (2008) The Influence of Bread Fortification with Wheat Germs on Bread Quality and Proteic Value. Journal of Agroalimentary Processes and Technologies, 14, 227-231.

[23] Gomez, M., Gonzalez, J. and Oliete, B. (2012) Effect of Extruded Wheat Germ on Dough Rheology and Bread Quality. Food and Bioprocess Technology, 5, 2409-2418. http://dx.doi.org/10.1007/s11947-011-0519-5

[24] Bilgicli, N. and Levent, H. (2013) Improvement of Nutritional Properties of Cake with Wheat Germ and Resistant Starch. Journal of Food and Nutrition Research, 52, 210-218.

[25] Levent, H. and Bilgicli, N. (2013) Quality Evaluation of Wheat Germ Cake Prepared with Different Emulsifiers. Journal of Food Quality, 36, 334-341. http://dx.doi.org/10.1111/jfq.12042

[26] Youssef, M.K.E. (2015) Wheat Germ is a Nutritional Treasure Important in Our Life. Environmental Bulletin, No. 7, January 2015, 17-18. Faculty of Agriculture, Assiut University, Assiut, Egypt. (In Arabic)

[27] Youssef, M.K.E. (2015) Wheat Germ Healthful Protective Functional Food. Assiut Journal of Environmental Studies, No. 41, January 2015, 75-83. Assiut Center of Environmental Studies and Research, Assiut University, Assiut, Egypt. (In Arabic)

[28] Rao, H. and Manohar, S. (1999) Effects of Emulsifier Fat Level and Type on the Rheological Characteristics of Biscuit Dough and Quality of Biscuit. Journal of the Science of Food and Agriculture, 79, 1223-1231. http://dx.doi.org/10.1002/(SICI)1097-0010(19990715)79:10<1223::AID-JSFA346>3.0.CO;2-W

[29] Saba, N.H. (1997) Culinary is Science and Art. P. 685. Dar El-Maaref, Cairo. (In Arabic)

[30] Vatsala, C.N. and Hardias Rao, P. (1991) Studies on Invert Sugar for Use in Biscuits. Journal of Food Science and Technology, 28, 149-152.

[31] Manohar, R.S. and Rao, P.H. (1997) Effect of Mixing Period and Additives on the Rheological Characteristics of Dough and Quality of Biscuits. Journal of Cereal Science, 25, 197-206. http://dx.doi.org/10.1006/jcrs.1996.0081

[32] Larmond, E. (1977) Laboratory Methods of Sensory Evaluation of Food. Canadian Government Publishing Center, Ottawa.

[33] AOAC (2010) Official Methods of Analysis of Association of Official Analytical Chemists. 18th Edition, Washington, DC.

[34] Seleet, R. (2010) The Analysis of Nutrients in Foods. Academic Press. Inc., London.

[35] Isaac, R.A. and Johnson, W.A. (2002) Elemental Analysis of Plant Tissue by Plasma Emission Spectroscopy. Colla- 
borative Study. Journal of the Association of Official Analytical Chemists, 68, 499-505.

[36] AOAC (2005) Official Methods of Analysis of Association of Official Analytical Chemists. 18th Edition, Washington, DC.

[37] AOAC (2012) Official Methods of Analysis of Association of Official Analytical Chemists. 19th Edition, Washington, DC.

[38] Ordriozola-Serrano, I., Hernandez, T. and Bellso, O.M. (2007) Comparative Evaluation of UV-HPLC Methods and Reducing Agents to Determine Vitamin C in Fruits. Food Chemistry, 105, 1151-1158.

[39] Albala-Hurtado, S., Veciana-Nugues, M.T., Izquierdo-Pulido, M. and Marine-Font, A. (1997) Determination of Water-Soluble Vitamins in Infant Milk by High-Performance Liquid Chromatography. Journal of Chromatography A, 778, 247-253.

[40] Gomis, D.B., Fernadert, M.P. and Gutiérrez Alvarez, M.D. (2000) Simultaneous Determination of Fat-Soluble Vitamins and Provitamins in Milk by Microcolumn Liquid Chromatography. Journal of Chromatography A, 891, 109-114.

[41] Baxter, J.H. (1996) Amino Acids. In: Nollet, L.M.L., Ed., Handbook of Food Analysis, Vol. I, Marcel Dekker. Inc., New York, 179-228.

[42] Sastry, C. and Tummuru, M. (1995) Spectrophotometric Determination of Tryptophan in Protein. Journal of Food Science and Technology, 22, 146-147.

[43] Wu, S.P. (2009) A Study on Technology and Quality of Steamed Bread Made of Wheat Germ. Cereal and Feed Industry, No. 3, 27-29.

[44] Steele, R.J. (1981) The Mineral Content of Some Australian Wheat Germ, Bran and Bran-Based Foods. Food Technology in Australia, 33, 412-414.

[45] Szira, F., Monostori, I., Galiba, G., Rakszegi, M. and Balint, A.F. (2014) Micronutrient Contents and Nutrional Wheat Varieties-A Survey in Hungary. Cereal Research Communications, 42, 293-302. http://dx.doi.org/10.1556/CRC.2013.0059

[46] Zia-UI-Haq. M., Riaz, M., DeFeo, V., Jaafar, H.Z.E. and Moga, M. (2014) Rubus fruticosus L.: Constituents, Biological Activities and Health Related Uses. Molecules, 19, 10998-11029. http://dx.doi.org/10.3390/molecules190810998

[47] Zia-UI-Haq, M., Ahmad, S., Imran, I., Ercisli, S. and Moga, M. (2015) Nutritional Quality of Food Depends Directly on the Quantity and Composition of the Minerals It Contains.

[48] Zia-Ul-Haq, M., Ahmad, S., Imran, I., Ercisli, S. and Moga, M. (2015) Compositional Studies of Grewia asiatica L. Seeds Grown in Pakistan. Comptes rendus de l'Académie bulgare des Sciences, 68, 191-200.

[49] Engelsen, M.M. and Hunsen, A. (2009) Tocopherol and Tocotrienol Content in Commercial Wheat Mill Streams. Cereal Chemistry, 86, 499-502. http://dx.doi.org/10.1094/CCHEM-86-5-0499

[50] Hassanun, M.M.M., Abdel-Razek, A.G., Rudzinska, M. Siger, A., Ratusz, K. and Przybylski, R. (2014) Phytochemcial Contents and Oxidative Stability of Oils from Non-Traditional Sources. European Journal of Lipid Science and Technology, 116, 1563-1571. http://dx.doi.org/10.1002/ejlt.201300475

[51] Knowles, J., Watkinson, C. and Johnstone, I. (2014) Extraction of Wheat Germ: The Production of Wheat Germ Oil and Defatted Stabilized Wheat Germ. Lipid Technology, 26, 157-161. http://dx.doi.org/10.1002/lite.201400038

[52] Baldini, V.L.S., Laderoza, M., Draetta, I. and Dos, S. (1982) Chemical and Biochemical Characterization of Wheat Germ and Maize Germ. Coletanea do Instituto de Techologia de Alimentos, 12, 1-14.

[53] Ke-Xue, Z., Hui-Ming, Z. and Hai-Feng, Q. (2006) Comparative Study of Chemical Composition and Physico-Chemical Properties of Defatted Wheat Germ Flour and Its Protein Isolate. Journal of Food Biochemistry, 30, 321-341.

[54] Umair, A., Muhammad, A. and Tahir, Z. (2007) Nutritional Assessment of Cookies Supplemented with Defatted Wheat Germ. Food Chemistry, 102, 124-128. 